\title{
The prognostic value of vascular endothelial growth factor in 574 node-negative breast cancer patients who did not receive adjuvant systemic therapy
}

\section{P Manders*, 1,2, LVAM Beex', VCG Tjan-Heijnen', J Geurts-Moespot ${ }^{2}$, TH Van Tienoven², JA Foekens ${ }^{3}$ and CGJ Sweep ${ }^{2}$}

'Department of Medical Oncology, University Medical Centre Nijmegen, Nijmegen, The Netherlands; ${ }^{2}$ Department of Chemical Endocrinology, University Medical Centre Nijmegen, Nijmegen, The Netherlands; ${ }^{3}$ Department of Medical Oncology, Rotterdam Cancer Institute and University Hospital

Rotterdam, Rotterdam, The Netherlands

The growth and metastasising capacity of solid tumours are dependent on angiogenesis. Vascular endothelial growth factor is a mediator of angiogenesis. In this study we investigated whether vascular endothelial growth factor is associated with the natural course of the disease in primary invasive breast cancer. In 574 tumours of patients with node-negative invasive breast cancer the cytosolic levels of vascular endothelial growth factor were measured using a quantitative enzyme-linked immunosorbent assay. These patients did not receive adjuvant systemic therapy and were followed for a median follow-up time of 61 months (range 2-155 months) after the primary diagnosis. Correlations with well-known prognostic factors, and univariate and multivariate survival analyses were performed. Vascular endothelial growth factor level was positively associated with age and tumour size $(P=0.042$ and $P=0.029$, respectively). In addition, vascular endothelial growth factor level was inversely, but weakly correlated with progesterone receptor levels $(P g R)\left(r_{s}=-0.090, P=0.035\right)$. A high vascular endothelial growth factor level (equal or above the median level of $0.53 \mathrm{ng} \mathrm{mg}^{-1}$ protein) predicted a reduced relapse-free survival and overall survival in the univariate survival rate analysis (for both $P=0.005$ ). In the multivariate analysis as well, vascular endothelial growth factor showed to be an independent predictor of poor relapse-free survival and overall survival $(P=0.045$ and $P=0.029$, respectively), in addition to age, tumour size and PgR. The results show that cytosolic levels of vascular endothelial growth factor in tumour tissue samples are independently indicative of prognosis for patients with node-negative breast cancer who were not treated with adjuvant systemic therapy. This implies that vascular endothelial growth factor is related with the natural course of breast cancer progression.

British Journal of Cancer (2002) 87, 772-778. doi:I0.1038/sj.bjc.6600555 www.bjcancer.com

(C) 2002 Cancer Research UK

Keywords: angiogenesis; node-negative breast cancer; prognostic value; vascular endothelial growth factor

The growth of solid tumours and their metastatic spread is angiogenesis-dependent (Folkman, 1990, 1995). Angiogenesis that results in tumour microvascularity is an acknowledged early requirement for both tumour growth and dissemination (Ellis and Fidler, 1996). The change to the angiogenic phenotype may be due to the over-expression of a number of endothelial growth factors, such as vascular endothelial growth factor (VEGF) (Folkman, 1995). VEGF works as a principal mediator of normal and pathological angiogenesis (Ferrara and Davis-Smyth, 1997) and is secreted by a wide variety of cell types, including neutrophils, platelets and tumour cells (Senger et al, 1993; Amoroso et al, 1997; Taichman et al, 1997; Verheul et al, 1997). Furthermore, tumour associated stroma has also been shown to produce VEGF (Fukumura et al, 1998). VEGF consists of several splice variants yielding proteins of 121, 145, 165, 189, and 206 amino acids (Houck et al, 1991; Veikkola et al, 2000). In tissue, $\mathrm{VEGF}_{165}$ is

*Correspondence: P Manders; Department of Chemical Endocrinology 530, University Medical Centre Nijmegen, P.O. Box 9I0I, NL-6500 HB Nijmegen, The Netherlands; E-mail: p.manders@ace.azn.nl

Received 28 March 2002; revised 21 June 2002; accepted 3 July 2002 the predominant isoform, and $\mathrm{VEGF}_{121}$ and $\mathrm{VEGF}_{165}$ are secreted into the circulation (Neufeld et al, 1999). Furthermore, related peptides have been described, i.e. VEGF-B, C, D and E (Neufeld et al, 1999).

Many types of malignant human tumours have been shown to produce VEGF. In previous studies the prognostic value of VEGF in patients with different malignancies, e.g. malignancies of the female tract (Abulafia et al, 1999; Hazelton et al, 1999; Santin et al, 1999; Tjalma et al, 2000; Boss et al, 2001), prostate (Bok et al, 2001), colon (Cascinu et al, 2001), urinary bladder (Sato et al, 1998; Crew et al, 1999), renal cell (Nicol et al, 1997) and thyroid gland (Lennard et al, 2000) has been investigated.

The prognostic value of VEGF has also been evaluated in invasive breast cancer in previous descriptive, retrospective studies (Gasparini et al, 1997, 2001; Eppenberger et al, 1998; Linderholm et al, 1998, 1999, 2000; Coradini et al, 2001). Two of these evaluated VEGF in heterogeneous series of patients including both node-negative and node-positive patients (Eppenberger et al, 1998; Linderholm et al, 2000). Five studies investigated the prognostic value of VEGF only in node-negative patients (Gasparini et al, 1997, 2001; Linderholm et al, 1998, 1999; Coradini et al, 2001). In three studies both treated and untreated patients were 
included (Eppenberger et al, 1998; Linderholm et al, 1998, 2000). Linderholm et al (1999) focused on the node-negative patients that were treated with radiotherapy. These previous studies have concluded that the concentration of VEGF was of prognostic value for relapse-free survival (RFS) (Gasparini et al, 1997, 2001; Eppenberger et al, 1998; Linderholm et al, 1999; Coradini et al, 2001) and/or overall survival (OS) (Gasparini et al, 1997; Linderholm et al, 1998, 1999, 2000) in different groups of patients.

In general, node-negative breast cancer patients who were treated with primary surgery have a relatively good prognosis, however, about $30 \%$ of these patients will develop distant metastasis within 10 years (Fisher et al, 1983; Saez et al, 1989). Prognostic factors are needed to separate node-negative patients into low-risk and high-risk groups in terms of the probability of recurrence and to focus the treatment efforts on patients at high risk. Importantly, to establish the prognostic value of a specific factor, the investigated patients should not have received adjuvant systemic therapy, because this may affect the relationship of the factor with the natural course of the disease. Three of the above mentioned studies included only patients who were not treated with adjuvant systemic therapy, but they did not take all established prognostic indicators into account in the performed analyses (Gasparini et al, 1997, 2001; Coradini et al, 2001). The principal aim of this study was to investigate the prognostic value of VEGF for RFS and OS in patients with node-negative breast cancer, who were not treated with adjuvant systemic therapy.

\section{PATIENTS AND METHODS}

\section{Patients}

A series of 1325 patients with operable breast cancer who underwent resection of their primary tumour between January 1987 and December 1996 were selected by the availability of frozen tissue in our tumour bank. This bank contains frozen tumour tissue of patients with breast cancer from nine different hospitals of the Comprehensive Cancer Center East in The Netherlands, because in this hospital (University Medical Centre, Nijmegen) the measurement of oestrogen receptor (ER) and progesterone receptor (PgR) levels, by means of the ligand-binding assay, was centrally done for these hospitals. The clinical data had to be retrospectively collected from these nine hospitals. To determine the prognostic value of VEGF, patients were selected by having node-negative breast cancer and by not having received adjuvant systemic therapy $(n=666)$. Thirty-two patients had evidence of distant metastases at the time of diagnosis and eight had evidence of disease within 1 month after primary surgery. These patients were all excluded. Patients with previous diagnosis of carcinoma, with the exception of basal cell skin cancer were also excluded $(n=20)$, as were patients with bilateral breast cancer $(n=6)$ and patients with only carcinoma in situ $(n=26)$. In total, 574 patients were considered assessable. Patients underwent a modified radical mastectomy $(n=345)$ or a breast conserving lumpectomy with axillary lymph node dissection plus complementary radiotherapy $(n=225)$. There were also four patients who were treated by breast conserving lumpectomy who did not receive additional radiotherapy. Of the patients who underwent a modified radical mastectomy, 64 received complementary radiotherapy. A resection was considered complete when there were no tumour cells in the inked border of the histological section. In case the margin was not free, a re-resection or breast ablation was performed whenever possible or additional radiotherapy was given. The median followup time was 61 months (range 2-155 months). The median age was 60 years (range 31-88 years). Further characteristics of patients and tumours are listed in Table 1.

Of the 574 patients included in this study, 116 patients $(20 \%)$ showed evidence of relapse of disease during follow-up. The first
Table I Categorical distributions of baseline characteristics in all patients

\begin{tabular}{|c|c|c|}
\hline \multirow[b]{2}{*}{ Variable } & \multicolumn{2}{|c|}{ Total group of patients ${ }^{\mathrm{a}}$} \\
\hline & $N=574$ & (\%) \\
\hline $\begin{array}{l}\text { Age (years) } \\
\leqslant 40 \\
41-55 \\
56-70 \\
>70\end{array}$ & $\begin{array}{r}42 \\
178 \\
234 \\
120\end{array}$ & $\begin{array}{l}(7.3) \\
(31.0) \\
(40.8) \\
(20.9)\end{array}$ \\
\hline $\begin{array}{l}\text { Menopausal status } \\
\text { Premenopausal } \\
\text { Postmenopausal }\end{array}$ & $\begin{array}{l}146 \\
428\end{array}$ & $\begin{array}{l}(25.4) \\
(74.6)\end{array}$ \\
\hline $\begin{array}{l}\text { Surgery } \\
\text { Breast saving procedure } \\
\text { Mastectomy }\end{array}$ & $\begin{array}{l}229 \\
345\end{array}$ & $\begin{array}{l}(39.9) \\
(60.1)\end{array}$ \\
\hline $\begin{array}{l}\text { Tumour type } \\
\text { Ductal } \\
\text { Lobular } \\
\text { Other }\end{array}$ & $\begin{array}{r}402 \\
69 \\
90\end{array}$ & $\begin{array}{l}(70.0) \\
(12.0) \\
(15.7)\end{array}$ \\
\hline $\begin{array}{l}\text { Tumour size } \\
\text { PTI } \\
\text { PT2 } \\
\text { PT3+4 }\end{array}$ & $\begin{array}{r}324 \\
223 \\
19\end{array}$ & $\begin{array}{r}(56.4) \\
(38.9) \\
(3.3)\end{array}$ \\
\hline $\begin{array}{l}\text { Histological grade } \\
\text { I } \\
\text { II } \\
\text { III } \\
\text { unknown }\end{array}$ & $\begin{array}{r}42 \\
144 \\
123 \\
265\end{array}$ & $\begin{array}{l}(7.3) \\
(25.1) \\
(21.4) \\
(46.2)\end{array}$ \\
\hline $\begin{array}{l}\text { ER (fmol } \mathrm{mg}^{-1} \text { protein) } \\
\quad<10 \\
\quad \geqslant 10\end{array}$ & $\begin{array}{l}138 \\
407\end{array}$ & $\begin{array}{l}(24.0) \\
(70.9)\end{array}$ \\
\hline $\begin{array}{l}\operatorname{PgR}\left(\text { fmol } \mathrm{mg}^{-1} \text { protein) }\right. \\
\quad<10 \\
\quad \geqslant 10\end{array}$ & $\begin{array}{l}160 \\
385\end{array}$ & $\begin{array}{l}(27.9) \\
(67.1)\end{array}$ \\
\hline $\begin{array}{l}\text { VEGF ( } \mathrm{ng} \mathrm{m}^{-1} \text { protein) } \\
\quad<0.53 \\
\quad \geqslant 0.53\end{array}$ & $\begin{array}{l}286 \\
288\end{array}$ & $\begin{array}{l}(49.8) \\
(50.2)\end{array}$ \\
\hline
\end{tabular}

aecause of missing values, numbers do not always add up to 574 (100\%).

relapses observed were: local recurrence in 25 patients, distant metastasis in 77 patients and 14 patients had both. Forty-six patients died due to breast cancer, while 24 patients died without evidence of disease at last follow-up. There were 22 patients who had a secondary primary tumour after the primary breast tumour. These were not considered as failures.

\section{Tumour tissue processing}

After the surgery, a representative part of the tumour was selected by the pathologist, frozen in liquid nitrogen and sent to this department (Department of Chemical Endocrinology). The primary breast cancer biopsies were stored in liquid nitrogen and pulverised in the frozen state with a microdismembrator as recommended by the European Organisation for Research and Treatment of Cancer (EORTC) for analysing ER and PgR (EORTC Breast CoOperative Group, 1980). The tissue powders were suspended in EORTC buffer, containing $20 \mathrm{mM} \mathrm{K} \mathrm{K}_{2} \mathrm{HPO}_{4} / \mathrm{KH}_{2} \mathrm{PO}_{4}, \quad 1.5 \mathrm{mM}$ $\mathrm{K}_{2}$ EDTA, $3 \mathrm{mM}$ sodium azide, $10 \mathrm{mM}$ monothioglycerol, $10 \%$ $\left(\mathrm{v} \mathrm{v}^{-1}\right)$ glycerol/water, $\mathrm{pH} 7.4$ and centrifuged at $800 \mathrm{~g}$ for $20 \mathrm{~min}$ at $4^{\circ} \mathrm{C}$. The supernatants were collected and subjected to further centrifugation for $1 \mathrm{~h}$ at $100000 \mathrm{~g}\left(4^{\circ} \mathrm{C}\right)$. A part of the high speed supernatants obtained (cytosols) were used for measurement of ER and PgR levels by ligand-binding assay as previously described (Koenders et al, 1977), the remaining cytosols were stored at $-80^{\circ} \mathrm{C}$ in liquid nitrogen. The protein concentrations 
were determined by the method of Lowry using BSA as the standard (Lowry et al, 1951).

\section{Vascular endothelial growth factor assay}

VEGF levels were determined in the primary breast tumour cytosols with an ELISA developed by this department (Department of Chemical Endocrinology) for the Receptor Biomarker Group (RBG) of the EORTC. The assay measures VEGF 165 and $\mathrm{VEGF}_{121}$, the main isoforms of VEGF. The details of the assay, including those of the specificity and performance, have been described elsewhere (Span et al, 2000).

To increase the sensitivity of the VEGF assay, the horseradish peroxidase labelled goat anti-rabbit detecting antibody was replaced by a goat anti-rabbit alkaline phosphatase conjugate (A-3687, Sigma Chemical Co, St. Louis, MO, USA). As substrate 4-methylumbelliferyl phosphate (M-6491, Molecular Probes, Eugene, OR, USA) in $10 \%$ diethanolamine was used. The reaction was stopped with $1 \mathrm{M} \mathrm{NaOH}$. Fluorescence was measured with a fluorometric plate reader (Fluoroskan, Lab Systems, Oy, Helsinki, Finland) using $355 \mathrm{~nm}$ excitation and $460 \mathrm{~nm}$ emission filters.

\section{Data analysis}

The median value of VEGF in this group of patients was used as the cut off value in the statistical analyses when analysing VEGF as a dichotomised variable.

To analyse interrelations between VEGF and various traditional parameters, Spearman rank correlations were calculated for continuous variables and the Kruskal-Wallis test for ordered variables.

Survival curves were generated using the method of Kaplan and Meier (1958). For the univariate survival rate analysis, RFS time (defined as the time from surgery until the diagnosis of recurrent disease) and OS time (defined as the time between date of surgery and death by any cause) were used as follow-up parameters. The survival curves only include the first 96 months of follow-up, because of the rapidly declining number of patients thereafter. Patients with events after 96 months were censored at 96 months

Cox univariate regression analysis was used in the analysis of the associations between the different variables and RFS and OS, and Cox multivariate regression analysis was used to evaluate the prognostic value of VEGF in addition to traditional factors (Cox, 1972). All computations were done with the SPSS statistical package (release 10.0.5, November 1999). Two-sided $P$-values below 0.05 were considered to be statistically significant.

\section{RESULTS}

\section{Distribution of VEGF}

Levels of VEGF protein were measured in 574 primary breast tumour cytosols. In this series, a wide range of concentrations of VEGF in cytosol, ranging from 0.00 to $48.03 \mathrm{ng} \mathrm{mg}^{-1}$ protein, was observed. The median cytosolic VEGF level was $0.53 \mathrm{ng} \mathrm{mg}$ protein. This value was used as cut off value to enable the analysis of VEGF as a categorised variable (low, $<0.53 \mathrm{ng} \mathrm{mg}^{-1}$ protein; high, $\geqslant 0.53 \mathrm{ng} \mathrm{mg}^{-1}$ protein).

\section{Relationships}

The tumour levels of VEGF were not related to those of ER $\left(r_{s}=-0.065, \quad P=0.132\right)$, or associated with histological grade $(P=0.082)$. Tumour VEGF levels were lower in patients with smaller, compared with those with larger tumours $(P=0.029)$. Tumours from young patients had lower levels of VEGF than those of patients who were older $(P=0.042)$. VEGF levels were higher in
PgR-negative, compared with receptor-positive tumours $\left(r_{s}=-0.090, P=0.035\right)$.

\section{Survival rate analyses}

The 5-year probability of RFS was $84 \%$ for patients with low VEGF levels and $75 \%$ for those with high VEGF levels. For OS, the 5-year probability was $93 \%$ for patients with a low VEGF level and $86 \%$ for those with a high level of VEGF.

Figure 1 show the results of the univariate RFS and OS rate analyses for the total group of patients. After 8 years $79 \%$ of the patients of whom the tumour had low VEGF levels $\left(<0.53 \mathrm{ng} \mathrm{mg}^{-1}\right.$ protein) were recurrence-free compared with $65 \%$ of those with high VEGF levels $(P=0.005)$. When VEGF was used as a continuous variable, also a significant relationship of higher VEGF levels with a poor RFS was observed $(P=0.004)$. Similarly, high VEGF levels were associated with a poor OS, both when analysed as a continuous variable $(P=0.004)$ and as a dichotomised variable $(P=0.005)$. At 8 years, $88 \%$ of the patients were alive in the group of patients with low VEGF levels compared with $78 \%$ in patients with high VEGF levels (Figure 1).

\section{Cox analysis}

In the Cox univariate regression analysis, young age, larger tumour size, and negative ER and PgR status were significantly associated with a poor RFS and OS (Table 2 and 3 ). In contrast, histological grade showed neither a significant association with RFS nor with OS. Since VEGF was shown to be of prognostic value in univariate analysis, Cox multivariate analysis was performed to evaluate whether it might significantly add to the contribution of the traditional prognostic factors.

In the final multivariate model, VEGF did still contribute to the prognostic information already provided by the traditional prognostic factors in the analysis for both RFS and OS (Table 2, RFS: $\mathrm{HR}=1.56, P=0.029$; Table 3, OS: $\mathrm{HR}=1.75, P=0.045$ ). Together with VEGF, age and PgR were significantly associated with both RFS and OS, while ER and histological grade were not. Tumour size was only significantly associated with RFS.

\section{DISCUSSION}

In this retrospective study, the prognostic value of VEGF was evaluated in 574 node-negative patients with primary breast cancer. None of these patients were treated with adjuvant systemic therapy, thus enabling the study of VEGF in relation to the natural course of the disease. VEGF levels were found to be positively associated with tumour size and negatively associated with ER and PgR status. A high level of VEGF ( $\geqslant 0.53 \mathrm{ng} \mathrm{mg}^{-1}$ protein) was shown to independently predict a short RFS and OS in patients with nodenegative breast cancer, in addition to age, tumour size and PgR.

Of note, these results in fact support the conclusion reported by other investigators, i.e. that VEGF is indeed of prognostic significance in breast cancer (Gasparini et al, 1997, 2001; Eppenberger et al, 1998; Linderholm et al, 1998, 1999, 2000; Coradini et al, 2001). Three of the previous studies investigated the prognostic value of VEGF in node-negative patients who were not treated with adjuvant systemic therapy, which were similar to the current study (Gasparini et al, 1997, 2001; Coradini et al, 2001). Gasparini et al (1997) reported that VEGF was an independent prognostic factor of RFS and OS in multivariate analyses in a smaller group of node-negative patients with primary breast cancer $(n=260)$, who were not treated with adjuvant systemic therapy. Unfortunately, they did not take age and histological grade into account in the multivariate analysis, although these are established prognostic indicators. In another study of Gasparini et al (2001) on the prognostic value of thrombospondins- 1 and -2 and their correlation 
A

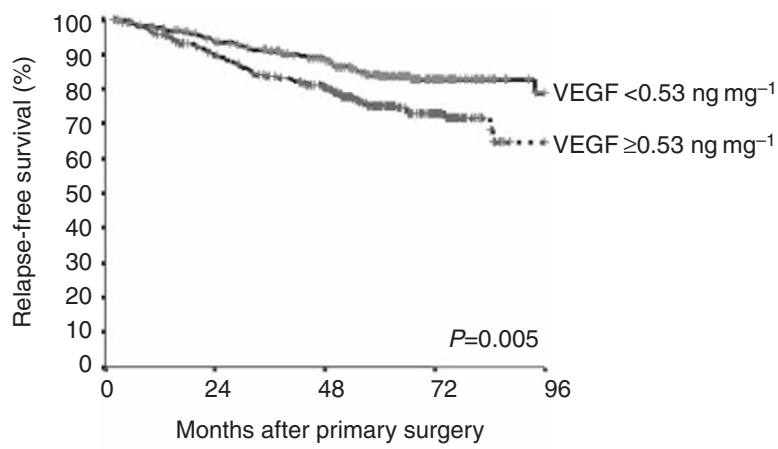

At risk

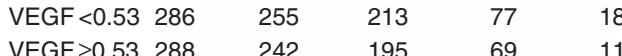

B

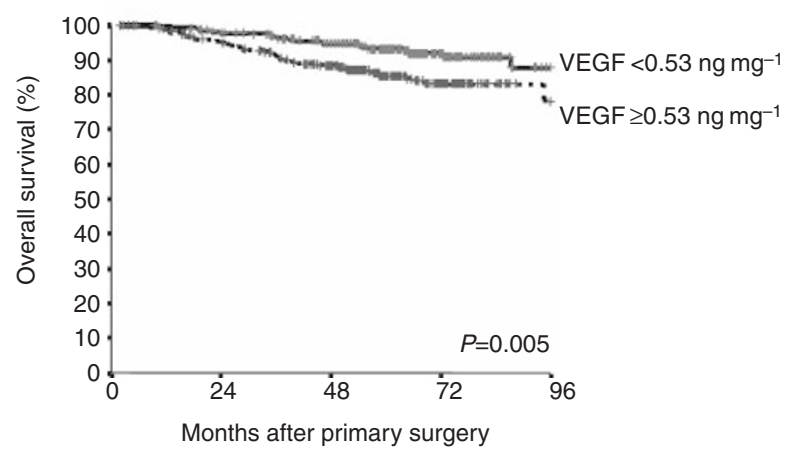

At risk

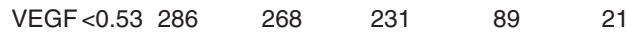

VEGF $\geq 0.53 \quad 288 \quad 261 \quad 211 \quad 76 \quad 16$

Figure I RFS (A) and OS (B) as a function of VEGF values. For each data set original VEGF values in the primary breast tumours were divided into two groups: < or $\geqslant 0.53 \mathrm{ng} \mathrm{\textrm {mg } ^ { - 1 }}$ protein. Events indicate the number of patients at risk in each group. Patients at risk at 0, 24, 48, 72 and 96 months after primary surgery are indicated.

with VEGF and thymidine phosphorylase, VEGF was statistically significant for RFS in 168 node-negative patients, who were not treated with adjuvant systemic therapy, but again they did not take all established prognostic factors into account in the multivariate analysis, e.g. age, histological grade, ER and PgR. In a study of Coradini et al (2001) on the contribution of VEGF to the Nottingham prognostic index, VEGF was of borderline significance for RFS in 226 node-negative patients who were not treated with adjuvant systemic therapy.

Eppenberger et al (1998) showed that VEGF was prognostically significant for poor RFS in 305 node-negative and node-positive breast cancer patients. However, the investigators also included patients who received adjuvant systemic therapy, which makes it more difficult to draw conclusions about the true prognostic impact of VEGF. In the study of Linderholm et al (1998), VEGF was also statistically significantly associated with OS in the multivariate analysis in 525 node-negative patients, but again patients who had received adjuvant systemic therapy were included. Moreover, these authors only investigated the association with OS and not with RFS. In another study Linderholm et al (1999) reported that VEGF was of borderline significance for OS in the multivariate analysis in a small group of node-negative patients who were treated with radiotherapy. Linderholm et al (2000) investigated the prognostic value of p53 and VEGF in node-negative breast cancer patients. In this study VEGF was also statistically significantly associated with OS but not with RFS in the multivariate analysis $(n=485)$, but again patients who had received adjuvant systemic therapy were included.

In the above mentioned studies, a clear distinction between the prognostic $v s$ predictive value of a factor was not always made. In an earlier study by Foekens et al (2001) on the predictive value of VEGF in breast cancer patients with advanced disease, it was shown that a high VEGF level predicts a poor efficacy of both tamoxifen and chemotherapy in advanced breast cancer. It is important to stress, that to determine the prognostic value of a marker, patients who did not receive adjuvant systemic treatment should ideally be studied. In addition, the primary endpoint of such analyses should be RFS and not OS, as for the latter, the impact of systemic adjuvant treatment after relapse is also taken into account.

In the current study the histological grade is missing for $46 \%$ of the patients. In previous studies $20-25 \%$ of the patients had a missing value for this variable (Eppenberger et al, 1998; Linderholm et al, 1998, 1999, 2000) or it was not included in the analyses (Gasparini et al, 1997, 2001). Coradini et al (2001) included the Nottingham prognostic index, which is based on morphopathologic features, i.e. lymph node status, tumour size and histological grade. Also, in the current study, the histological grade was included in the univariate Cox analyses for those patients for which it was available, but probably due to a substantial number of missing data, it was not a significant predictor of relapse.

It was not the intention of this study to find an optimal cut off value for VEGF in cytosols of tumour tissue of breast cancer patients and it was decided to use the median level in the group of patients. From a biological point of view, such an arbitrary assignment might be inappropriate. Alternatively, every conceivable cut off value might be sequentially examined to maximise the separation of the RFS and OS curves. However, if the total data set would have been used to find the optimal cut off value, one still needs an independent data set to validate this cut off value (McGuire, 1991). Further studies are needed to determine the optimal cut off value for clinical use. Two of the before mentioned studies also used the median value as the cut off value (Linderholm et al, 1998, 1999). Eppenberger et al (1998) used the first quartile value to dichotomise the sample set. On the other hand, Gasparini et al $(1997,2001)$ used a spline function and Linderholm et al (2000) identified the cut off value with the smallest $P$-value and the highest relative risk for death. Coradini et al (2001) did not dichotomise the sample set, they used the 25th, 50th and 75th percentiles for VEGF.

Several studies documented that in invasive breast cancer the level of VEGF is highly associated with the degree of angiogenesis, assessed by microvessel count (Toi et al, 1995b; Anan et al, 1996; Obermair et al, 1997). Previous investigators have studied the prognostic value of the degree of vascularisation of the tumour by measuring intratumoural microvessel density (MVD). Some of them demonstrated that MVD is of prognostic value for patients with node-negative primary breast cancer (Gasparini et al, 1994; Obermair et al, 1995; Toi et al, 1995a), but not all (Ellis and Fidler, 1995).

It is of clinical interest to establish new prognostic factors that, in addition to the factors used up till now, could distinguish subgroups of patients with node-negative invasive breast cancer with a high risk for relapse that might benefit from adjuvant systemic therapy (National Institutes of Health Consensus Development Panel, 1992; Henderson, 1992; Osborne, 1992; Gasparini et al, 1993). Knowledge of these factors is also important for stratification in phase III trials and to explain different outcomes between trials with a comparable design. 
Table 2 Cox univariate and multivariate analysis of relapse-free survival

\begin{tabular}{|c|c|c|c|c|c|c|}
\hline \multirow[b]{2}{*}{ Factor } & \multicolumn{3}{|c|}{ Univariate analysis } & \multicolumn{3}{|c|}{ Multivariate analysis $^{\mathrm{a}}$} \\
\hline & $P$-value & $H R^{b}$ & $(95 \% \mathrm{Cl})^{\mathrm{b}}$ & $P$-value & $\mathbf{H R}^{\mathrm{b}}$ & $(95 \% \mathrm{Cl})^{\mathrm{b}}$ \\
\hline $\begin{array}{c}\text { Age (years) } \\
\leqslant 40 \\
41-55 \\
56-70 \\
>70\end{array}$ & $<0.001$ & $\begin{array}{l}1 \\
0.23 \\
0.30 \\
0.29\end{array}$ & $\begin{array}{l}(0.13-0.41) \\
(0.18-0.52) \\
(0.16-0.54)\end{array}$ & $<0.00 \mid$ & $\begin{array}{l}1 \\
0.26 \\
0.32 \\
0.31\end{array}$ & $\begin{array}{l}(0.14-0.47) \\
(0.18-0.55) \\
(0.16-0.58)\end{array}$ \\
\hline $\begin{array}{l}\text { Histological grade } \\
\text { | } \\
\text { III }\end{array}$ & 0.060 & $\begin{array}{l}1 \\
2.32 \\
3.51\end{array}$ & $\begin{array}{l}(0.70-7.69) \\
(1.07-11.49)\end{array}$ & & & \\
\hline $\begin{array}{l}\text { Tumour size } \\
\text { PTI } \\
\text { PT2 } \\
\text { PT3+4 }\end{array}$ & 0.003 & $\begin{array}{l}1 \\
1.65 \\
3.03\end{array}$ & $\begin{array}{l}(1.12-2.42) \\
(1.38-6.68)\end{array}$ & 0.018 & $\begin{array}{l}1 \\
1.34 \\
3.01\end{array}$ & $\begin{array}{l}(0.89-2.03) \\
(1.38-6.95)\end{array}$ \\
\hline $\begin{array}{l}\text { ER status }{ }^{c} \\
\text { Negative } \\
\text { Positive }\end{array}$ & 0.003 & $\begin{array}{l}1 \\
0.56\end{array}$ & $(0.38-0.82)$ & & & \\
\hline $\begin{array}{c}\text { PgR status }{ }^{c} \\
\text { Negative } \\
\text { Positive }\end{array}$ & $<0.001$ & $\begin{array}{l}1 \\
0.39\end{array}$ & $(0.27-0.56)$ & $<0.001$ & $\begin{array}{l}1 \\
0.48\end{array}$ & $(0.32-0.7 I)$ \\
\hline $\begin{array}{l}\text { VEGF levels } \\
\text { Low } \\
\text { High }\end{array}$ & 0.005 & 1.73 & $(1.18-2.52)$ & 0.029 & 1.56 & $(1.05-2.33)$ \\
\hline
\end{tabular}

${ }^{a}$ The final multivariate model with all the factors known included 538 patients. ${ }^{\text {b Hazard ratio }}$ (95\% confidence interval) of univariate and multivariate analysis. ${ }^{~ C}$ Cut off points used for ER and PgR,

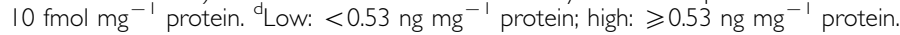

Table 3 Cox univariate and multivariate analysis of overall survival

\begin{tabular}{|c|c|c|c|c|c|c|}
\hline \multirow[b]{2}{*}{ Factor } & \multicolumn{3}{|c|}{ Univariate analysis } & \multicolumn{3}{|c|}{ Multivariate analysis $^{\mathrm{a}}$} \\
\hline & $P$-value & $H^{b}{ }^{b}$ & $(95 \% \mathrm{Cl})^{\mathrm{b}}$ & $P$-value & $H_{R^{b}}$ & $(95 \% \mathrm{Cl})^{\mathrm{b}}$ \\
\hline $\begin{array}{c}\text { Age (years) } \\
\leqslant 40 \\
41-55 \\
56-70 \\
>70\end{array}$ & $<0.001$ & $\begin{array}{l}1 \\
0.13 \\
0.38 \\
0.58\end{array}$ & $\begin{array}{l}(0.05-0.33) \\
(0.19-0.76) \\
(0.27-1.23)\end{array}$ & $<0.001$ & $\begin{array}{l}1 \\
0.15 \\
0.37 \\
0.54\end{array}$ & $\begin{array}{l}(0.06-0.40) \\
(0.18-0.76) \\
(0.30-1.38)\end{array}$ \\
\hline $\begin{array}{l}\text { Histological grade } \\
\text { I } \\
\text { II } \\
\text { II }\end{array}$ & 0.291 & $\begin{array}{l}1 \\
2.06 \\
2.86\end{array}$ & $\begin{array}{l}(0.47-9.98) \\
(0.67-12.31)\end{array}$ & & & \\
\hline $\begin{array}{l}\text { Tumour size } \\
\text { PTI } \\
\text { PT2 } \\
\text { PT3+4 }\end{array}$ & 0.009 & $\begin{array}{l}1 \\
2.07 \\
3.25\end{array}$ & $\begin{array}{l}(1.22-3.54) \\
(1.13-9.37)\end{array}$ & & & \\
\hline $\begin{array}{c}\text { ER status }^{c} \\
\text { Negative } \\
\text { Positive }\end{array}$ & 0.004 & l 0.47 & $(0.28-0.79)$ & & & \\
\hline $\begin{array}{c}\text { PgR status }{ }^{c} \\
\text { Negative } \\
\text { Positive }\end{array}$ & $<0.001$ & $\begin{array}{l}1 \\
0.31\end{array}$ & $(0.19-0.51)$ & $<0.001$ & $\begin{array}{l}1 \\
0.34\end{array}$ & $(0.20-0.57)$ \\
\hline $\begin{array}{l}\text { VEGF levels } \\
\text { Low } \\
\text { High }\end{array}$ & 0.005 & $\begin{array}{l}1 \\
2.12\end{array}$ & $(1.25-3.59)$ & 0.045 & 1.75 & $(1.01-3.02)$ \\
\hline
\end{tabular}

aThe final multivariate model with all the factors known included 545 patients. ${ }^{b}$ Hazard ratio $95 \%$ confidence interval) of univariate and multivariate analysis. ${ }^{\circ} \mathrm{Cut}$ off points used for ER and PgR,

$10 \mathrm{fmol} \mathrm{mg}^{-1}$ protein. ${ }^{d} L o w:<0.53 \mathrm{ng} \mathrm{mg}^{-1}$ protein; high: $\geqslant 0.53 \mathrm{ng} \mathrm{mg}^{-1}$ protein.

In conclusion, our data suggest that VEGF is an independent prognostic factor for RFS and OS in patients with node-negative breast cancer. The present findings indicate that VEGF represents a biologic marker of breast tumour angiogenesis. Further studies are warranted to investigate whether patients with high VEGF levels are more likely to gain benefit from (antiangiogenic) systemic adjuvant therapy. 


\section{ACKNOWLEDGEMENTS}

We thank the contributors, especially the surgeons and internists, of the community hospitals in the region: Ziekenhuiscentrum Apeldoorn, Apeldoorn, Rijnstate Ziekenhuis, Arnhem, Maaszieken- huis, Boxmeer, Deventer Ziekenhuis, Deventer, Gelderse Vallei, Ede, UMC Nijmegen and Canisius-Wilhemina Ziekenhuis, Nijmegen, Streekziekenhuis Zevenaar, Zevenaar, and Nieuw Spitaal, Zutphen, for their assistance in collecting the patients' clinical follow-up data.

\section{REFERENCES}

Abulafia O, Triest WE, Sherer DM (1999) Angiogenesis in malignancies of the female genital tract. Gynecol Oncol 72: 220-231

Amoroso A, Del Porto F, Di Monaco C, Manfredini P, Afeltra A (1997) Vascular endothelial growth factor: A key mediator of neoangiogenesis. A review. Eur Rev Med Pharmacol Sci 1: 17-25

Anan K, Morisaki T, Katano M, Ikubo A, Kitsuki H, Uchiyama A, Kuroki S, Tanaka M, Torisu M (1996) Vascular endothelial growth factor and platelet-derived growth factor are potential angiogenic and metastatic factors in human breast cancer. Surgery 119: 333-339

Bok RA, Halabi S, Fei DT, Rodriquez CR, Hayes DF, Vogelzang NJ, Kantoff P, Shuman MA, Small EJ (2001) Vascular endothelial growth factor and basic fibroblast growth factor urine levels as predictors of outcome in hormone-refractory prostate cancer patients: a cancer and leukemia group B study. Cancer Res 61: 2533-2536

Boss EA, Massuger LFAG, Thomas CMG, Geurts-Moespot A, Boonstra H, Sweep CGJ (2001) Vascular endothelial growth factor in ovarian cyst fluid. Cancer 91: $371-377$

Cascinu S, Graziano F, Valentini M, Catalano V, Giordani P, Stacciolo MP, Rossi C, Baldelli AM, Grianti C, Muretto P, Catalano G (2001) Vascular endothelial growth factor expression, S-phase fraction and thymidylate synthase quantitation in node-positive colon cancer: Relationships with tumour recurrence and resistance to adjuvant therapy. Ann Oncol 12: $239-244$

Coradini D, Boracchi P, Daidone MG, Pellizzaro C, Miodini P, Ammatuna M, Tomasic G, Biganzoli E (2001) Contribution of vascular andothelial growth factor to the Nottingham prognostic index in node-negative breast cancer. Br J Cancer 85: 795-797

Cox DR (1972) Regression models and life-tables. J R Statist Soc B 34: 187 220

Crew JP, O'Brien T, Bicknell R, Fuggle S, Cranston D, Harris AL (1999) Urinary vascular endothelial growth factor and its correlation with bladder cancer recurrence rates. J Urol 161: 799-804

Ellis LM, Fidler IJ (1995) Angiogenesis and breast cancer metastasis. Lancet 346: $388-390$

Ellis LM, Fidler IJ (1996) Angiogenesis and metastasis. Eur J Cancer 32A: $2451-2460$

EORTC Breast Co-operative group (1980) Revision of the standards for the assessment of hormone receptors in human breast cancer; Report of the second EORTC workshop, held on 16-17 March, 1979, in the Netherlands Cancer Institute. Eur J Cancer 16: 1513-1515

Eppenberger U, Kueng W, Schlaeppi JM, Roesel JL, Benz C, Mueller H, Matter A, Zuber M, Luescher K, Litschgi M, Schmitt M, Foekens JA, Eppenberger-Castori S (1998) Markers of tumour angiogenesis and proteolysis independently define high- and low-risk subsets of node-negative breast cancer patients. J Clin Oncol 16: 3129-3136

Ferrara N, Davis-Smyth TD (1997) The biology of vascular endothelial growth factor. Endocr Rev 18: 4-25

Fisher B, Bauer M, Wickerham DL, Redmond CK, Fisher ER (1983) Relation of number of positive axillary nodes to the prognosis of patients with primary breast cancer: an NSABP update. Cancer 52: 1551-1557

Foekens JA, Peters HA, Grebenchtchikov N, Look MP, Meijer-Gelder ME van, Geurts-Moespot A, Kwast TH van der, Sweep CGJ, Klijn JGM (2001) High tumor levels of vascular endothelial growth factor predict poor response to systemic therapy in advanced breast cancer. Cancer Res 61: $5407-5414$

Folkman J (1990) What is the evidence that tumors are angiogenesis dependent? J Natl Cancer Inst 82: 4-6

Folkman J (1995) Angiogenesis in cancer, vascular, rheumatoid and other disease. Nature Med 1: 27-31

Fukumura D, Xavier R, Sugiura T, Chen Y, Park EC, Lu N, Selig M, Nielsen G, Taksir T, Jain RK, Seed B (1998) Tumor induction of VEGF promoter activity in stromal cells. Cell 94: 715-725
Gasparini G, Pozza F, Harris AL (1993) Evaluating the potential usefulness of new prognostic and predictive indicators in node-negative breast cancer patients. J Natl Cancer Inst 85: 1206-1219

Gasparini G, Weidner N, Bevilacqua P, Maluta S, Dalla Palma P, Caffo O, Barbareschi M, Boracchi P, Marubini E, Pozza F (1994) Tumor microvessel density, p53 expression, tumor size, and peritumoral lymphatic vessel invasion are relevant prognostic markers in node-negative breast carcinoma. J Clin Oncol 12: 454-466

Gasparini G, Toi M, Gion M, Verderio P, Dittadi R, Hanatani M, Matsubara I, Vinante O, Bonoldi E, Boracchi P, Gatti C, Suzuki H, Tominaga T (1997) Prognostic significance of vascular endothelial growth factor in node-negative breast carcinoma. J Natl Cancer Inst 89: 139-147

Gasparini G, Toi M, Biganzoli E, Dittadi R, Fanelli M, Morabito A, Boracchi P, Gion M (2001) Thrombospondin-1 and -2 in node-negative breast cancer: Correlation with angiogenic factors, p53, cathepsin D, hormone receptors and prognosis. Oncology 60: 72-80

Hazelton D, Nicosia RF, Nicosia SV (1999) Vascular endothelial growth factor levels in ovarian cyst fluid correlate with malignancy. Clin Cancer Res 5: $823-829$

Henderson IC (1992) Breast cancer therapy. The price of success. $N$ Engl J Med 326: $1774-1775$

Houck KA, Ferrara N, Winer J, Cachianes G, Li B, Leung DW (1991) The vascular endothelial growth factor family: Identification of a fourth molecular species and characterization of alternative splicing. Mol Endocrinol 5: $1806-1814$

Kaplan EL, Meier P (1958) Nonparametric estimation from incomplete observations. Am Stat Assoc J 53: 457-481

Koenders AJM, Geurts-Moespot A, Zollingen S, Benraad T (1977) Progesterone and estradiol receptors in DMBA-induced mammary tumors before and after ovariectomy and after subsequent estradiol administration. In Progress in Cancer and therapy, Vol 4, Progesterone receptors in normal and neoplastic tissues, McGuire W, Raynaud J, Baulieu E (eds) pp 7184. New York: Raven Press

Lennard CM, Patel A, Wilson J, Reinhardt B, Tuman C, Fenton C, Blair E, Francis GL, Tuttle RM (2000) Intensity of vascular endothelial growth factor expression is associated with increased risk of recurrence and decreased disease-free survival in papillary thyroid cancer. Surgery 129: $552-558$

Linderholm B, Tavelin B, Grankvist K, Henriksson R (1998) Vascular endothelial growth factor is of high prognostic value in node-negative breast carcinoma. J Clin Oncol 16: 3121-3128

Linderholm B, Tavelin B, Grankvist K, Henriksson R (1999) Does vascular endothelial growth factor (VEGF) predict local relapse and survival in radiotherapy-treated node-negative breast cancer? Br J Cancer 81: 727 732

Linderholm B, Lindh B, Tavelin B, Garnkvist K, Henriksson R (2000) p53 and vascular endothelial growth factor (VEGF) expression predicts poor outcome in 833 patients with primary breast carcinoma. Int J Cancer 89: $51-62$

Lowry OH, Rosebrough NJ, Farr AL, Randall RJ (1951) Protein measurement with the folin phenol reagent. J Biol Chem 193: 265-275

McGuire WL (1991) Breast cancer prognostic factors: Evaluation guidelines. J Natl Cancer Inst 83: 154- 155

National Institutes of Health Consensus Development Panel (1992) Consensus statement: Treatment of early-stage breast cancer. Monogr Natl Cancer Inst 11: $1-5$

Neufeld G, Cohen T, Gengrinovitch P, Poltorak Z (1999) Vascular endothelial growth factor (VEGF) and its receptors. FASEB J 13: 9-22

Nicol D, Hii SI, Walsh M, Teh B, Thompson L, Kennett C, Gotley D (1997) Vascular endothelial growth factor expression is increased in renal cell carcinoma. J Urol 157: $1482-1486$ 
Obermair A, Kurz C, Czerwenka K, Thoma M, Kaider A, Wagner T, Gitsch G, Sevelda P (1995) Microvessel density and vessel invasion in lymph-nodenegative breast cancer: Effect on recurrence-free survival. Int $J$ Cancer 62: $126-131$

Obermair A, Kucera E, Mayerhofer K, Speiser P, Seifert M, Czerwenka K, Kaider A, Leodolter S, Kainz C, Zeillinger R (1997) Vascular endothelial growth factor (VEGF) in human breast cancer: Correlation with diseasefree survival. Int J Cancer 74: $455-458$

Osborne CK (1992) Prognostic factors for breast cancer: Have they met their promise? J Clin Oncol 10: 679-682

Saez RA, McGuire WL, Clark CMl (1989) Prognostic factors in breast cancer. Semin Surg Oncol 5: $102-110$

Santin AD, Hermonat PL, Ravaggi A, Cannon MJ, Pecorelli S, Parham GP (1999) Secretion of vascular endothelial growth factor in ovarian cancer. Eur J Gynaec Oncol 3: 177-181

Sato K, Sasaki R, Ogura Y, Shimoda N, Togashi H, Terada K, Sugiyama T, Kakinuma H, Ogawa O, Kato T (1998) Expression of vascular endothelial growth factor gene and its receptor (flt-1) gene in urinary bladder cancer. Tohoku J Exp Med 185: 173-184

Senger DR, Water L van de, Brown LF, Nagy JA, Yeo KT, Yeo TK, Berse B, Jackman RW, Dvorak AM, Dvorak HF (1993) Vascular permeability factor (VPF, VEGF) in tumor biology. Cancer Metastasis Rev 12: 303-324

Span PN, Grebenchtchikov N, Geurts-Moespot J, Westphal JR, Lucassen AMJ, Sweep CGJ (2000) EORTC receptor and biomarker study group report: A sandwich enzyme-linked immunosorbent assay for vascular endothelial growth factor in blood and tumor tissue extracts. Int J Biol Markers 15: $184-191$
Taichman NS, Young S, Cruchley AT, Taylor P, Paleolog E (1997) Human neutrophils secrete vascular endothelial growth factor. J Leukoc Biol 62 . $397-400$

Tjalma W, Weyler J, Weyn B, Marck E van, Daele A van, Dam P van, Goovaerts G, Buytaert P (2000) The association between vascular endothelia growth factor, microvessel density and clinicopathological features in invasive cervical cancer. Eur J Obstet Gynecol Rep Biol 92: 251-257

Toi M, Insada K, Suzuki H, Tominaga T (1995a) Tumor angiogenesis in breast cancer: Its importance as a prognostic indicator and the association with vascular endothelial growth factor expression. Breast Cancer Res Treat 36: $193-204$

Toi M, Insada K, Hoshina S, Suzuki H, Kondo S, Tominaga T (1995b) Vascular endothelial growth factor and platelet-derived endothelial cell growth factor are frequently coexpressed in highly vascularized human breast cancer. Clin Cancer Res 1: $961-964$

Veikkola T, Karkkainen M, Claesson-Welsh L, Alitalo K (2000) Regulation of angiogenesis via vascular endothelial growth factor receptors. Cancer Res 60: $202-212$

Verheul HMW, Hoekman K, Luykx-Bakker S de, Eekman CA, Folman CC, Broxterman HJ, Pinedo HM (1997) Platelet: transporter of vascular endothelial growth factor. Clin Cancer Res 3: 2187-2190 